\title{
PEMBERDAYAAN MASYARAKAT DALAM PENGOLAHAN HASIL PERTANIAN UBI JALAR DI DESA SELOTAPAK
}

\author{
Endah Asmawati ${ }^{1}$, Arif Herlambang ${ }^{2}$ \\ ${ }^{1}$ Jurusan Teknik Informatika, Fakultas Teknik, Universitas Surabaya \\ ${ }^{2}$ Jurusan Manajemen, Fakultas Bisnis dan Ekonomika, Universitas Surabaya, \\ 1endah@staff.ubaya.ac.id \\ 2arif_herlambang@staff.ubaya.ac.id
}

\begin{abstract}
Selotapak is one of the villages in the Trawas District area of Mojokerto Regency, East Java. This village is one of the sweet potato producing communities. At the time of harvest, the harvest reaches 40-50 tons per hectare. But often at the time of harvest, the price of sweet potatoes becomes very low. This price makes farmers unable to benefit, even many who lose. On the other hand, the storage period of sweet potatoes is also not long. The farmers must immediately sell their crops. Therefore another alternative is needed in marketing sweet potatoes so that the selling price can increase. The purpose of this activity is to provide knowledge to the community in processing sweet potatoes into superior products of the village. The goal is done by providing training in processing sweet potatoes into several products, namely flour, noodles, brownies, ice cream roll, and yogurt. The results of the activities is training modules in making superior products. Based on the training results, over $80 \%$ of the training participants feel the benefits of the training and the module easy to understand, so participants can practice it independently.
\end{abstract}

Keyword: sweet potato, PKK, superior products

\section{PENDAHULUAN}

Desa Selotapak merupakan salah satu desa yang terletak di wilayah Kecamatan Trawas. Desa ini terdiri dari 2 dusun, yaitu Dusun Selotapak dan Dusun Jaten. Terdapat berbagai organisasi masyarakat yang aktif di desa ini, salah satunya adalah PKK. Sebagian besar ibu PKK berprofesi sebagai ibu rumah tangga, sehingga setiap hari banyak waktu luang yang belum dimanfaatkan untuk menambah penghasilan keluarga. Setiap bulan, anggota PKK rutin mengadakan pertemuan di setiap dusun. Pada pertemuan rutin ini, agenda utama adalah arisan, kemudian dilanjutkan dengan pengumuman dan atau pemberian materi (jika ada). Pemberian materi kadang disampaikan oleh salah satu ibu PKK sendiri atau disampaikan oleh pihak luar. Isi materi bermacam-macam, seperti penyampaian informasi dari kecamatan atau kabupaten, atau bahkan pihak luar yang akan menawarkan produk. Harapan ibu-ibu, pada pertemuan rutin tersebut mereka bisa mendapatkan materi yang dapat menambah pengetahuan mereka, misalkan pelatihan pengolahan sampah organik dan anorganik, pengolahan lingkungan (bank sampah), atau pengolahan ubi jalar (pembuatan produk unggulan desa berbasis hasil pertanian lokal).

Masyarakat desa Selotapak mayoritas berprofesi sebagai petani. Hasil pertanian yang melimpah adalah ubi jalar. Pada saat panen hasil ubi jalar mencapai 40-50 ton per hektar, dan biasanya selalu dijual mentah. Saat panen raya harganya sangat rendah. Pernah terjadi pada saat panen raya, harga $1 \mathrm{~kg}$ ubi putih hanya Rp 700 per kilogram, dan ubi madu Rp 2.000 per $\mathrm{kg}$. Tentu saja hal ini membuat petani tidak bisa mendapatkan keuntungan, bahkan rugi. Ada beberapa petani yang tidak memanennya dan membiarkan ubi jalar tetap di sawah untuk dibajak pada masa tanam berikutnya, karena biaya panen lebih besar daripada hasil yang diperoleh. Petani terpaksa menjual hasil panennya ke tengkulak dengan harga rendah karena umur simpan ubi jalar relatif pendek, yaitu antara $4-5$ hari. Pendeknya umur simpan ubi jalar dikarenakan 
terdapatnya kandungan enzim polifenolase dalam lendir ubi jalar (Soetanto, 1998). Bahkan, apabila ubi jalar terserang bakteri Erwinia Chrysanthemi maka ubi jalar akan mengalami kerusakan hanya dalam 48 jam saja (Moyer, 1982).

Ubi jalar dapat diolah menjadi produk yang masa simpannya lebih lama, salah satunya dengan mengubah ubi jalar menjadi tepung ubi jalar. Kandungan nutrisi-nutrisi yang ada di ubi jalar seperti $\beta$-karoten (pada ubi jalar madu dan manohara) serta antosianin (ubi jalar ungu) dapat memberikan nilai lebih pada tepung ubi jalar dibandingkan tepung lainnya (Widjanarko, 2008). Tepung ubi jalar berpeluang mensubstitusi penggunaan terigu 10-100\% (Ginting E., 2011).

Ubi jalar merupakan salah satu hasil pertanian terbesar di daaerah Trawas. Jenisjenis ubi jalar yang dihasilkan antara lain varietas manohara, madu, ubi ungu dan ubi putih. Setiap varietas memiliki keunggulan sendiri-sendiri, misalkan manohara mempunyai keunggulan ukurannya yang besar dan warna umbinya putih kekuningan. Varietas madu mempunyai rasa yang manis dan memiliki kadar $\beta$-karoten (pro vit. A) yang tinggi. Ubi putih biasanya digunakan sebagai pencampur pembuatan saos tomat, karena rasanya yang hambar dan warnanya yang putih. Sedangkan ubi ungu mempunyai warna ungu pekat karena kandungan antosianin yang tinggi, dimana zat ini berfungsi sebagai anti oksidan. Dengan kandungan seperti itu, maka sayang sekali kalau ubi jalar tidak dimanfaatkan secara maksimal. Salah satu cara memanfaatkan ubi jalar ungu adalah mengolahnya biskuit ubi jalar(Syarfaini dkk, 2017). Pada penelitian yang telah dilakukan diperoleh kesimpulan bahwa biskuit ubi jalar ungu bisa menjadi makanan layak konsumsi sebagai makanan tambahan untuk memenuhi kebutuhan gizi (karbohidrat, protein, lemak, zat besi, dan vitamin C) setiap hari. Bahkan Rahayu P. (2012) menyatakan bahwa kandungan ubi jalar ungu (antioksidan, serat yang tinggi, dan karbohidrat dengan glikemik rendah) dapat mengurangi resiko hipertensi, dan diabetes mellitus ibu hamil trimester kedua. Ginting E. (2011) juga menyatakan bahwa Ubi jalar ungu potensial dimanfaatkan sebagai bahan pangan fungsional. Hal ini disebabkan ubi jalar ungu memiliki antosianin, pigmen yang berwarna ungu mempunyai aktivitas antioksidan dan kandungan serat pangannya bermanfaat untuk pencernaan. Selain itu indeks glikemiknya yang rendah sampai medium, juga merupakan nilai tambah ubi jalar sebagai pangan fungsional. Indeks glikemik adalah angka yang menunjukkan seberapa cepat makanan diubah menjadi glukosa. Makanan dengan indeks glikemik rendah lebih lambat dalam meningkatkan gula darah dibanding dengan makanan dengan indeks glikemik tinggi.

Meskipun manfaat ubi jalar ungu sangat banyak namun pemanfaatannya masih terbatas, sehingga perlu disosialisasikan teknik olahan yang sesuai dan menarik. Produk olahan dari ubi jalar segar maupun produk antara (tepung) berpeluang mensubstitusi penggunaan terigu 10-100\%. Ubi jalar ungu juga potensial digunakan sebagai bahan pewarna alami untuk makanan dan minuman. Pengembangan produksi dan pemanfaatan ubi jalar ungu sesuai dengan program unggulan daerah yang berbasis pada hasil pertanian local (Ginting E., 2011).

Makalah ini memaparkan kegiatan pengenalan dan pengaplikasian pembuatan produk berbahan dasar ubi jalar. Tujuan dari kegiatan ini adalah untuk menjawab permasalahan yang ada, yaitu bagaimana memberikan pengetahuan ke masyarakat untuk meningkatkan nilai ekonomis dan masa simpan ubi jalar, terutama pada masa panen, sehingga bisa menjadi produk unggulan desa. Pelaksanaan kegiatan dilakukan dengan membuat modul kegiatan dan memberikan pelatihan interaktif ke masyarakat, terutama ibu PKK. 
Menurut Trisnawati N.A.(2017), ibu PKK merupakan wanita yang mandiri. Hanya dengan diberikan pelatihan keterampilan saja, mereka dapat mengembangkannya sehingga tidak sedikit yang berhasil menciptakan usaha sendiri di rumah sesuai dengan kemampuan yang dimiliki. Ibu-ibu juga mempunyai kemampuan mengelola keuangan yang handal. Sehingga dengan kombinasi kedua keterampilan ini, ibu-ibu dapat berwirausaha untuk menambah pendapatan keluarga. Oleh sebab itu pada kegiatan ini dilakukan permberdayaan pada ibu-ibu PKK untuk melakukan pengolahan ubi jalar. Apabila hasil pengolahan sudah ada, dengan sendirinya akan ada penghasilan lain yang dapat meningkatkan perekonomian keluarga.

\section{METODE}

Pelaksanaan kegiatan dilakukan melalui beberapa tahapan. Tahapan tersebut meliputi: (1) diskusi dengan ibu PKK terkait kebutuhan dan harapannya dalam pengolahan ubi jalar, (2) dari diskusi ini, ditentukan pelatihan yang diperlukan beserta pembuatan modulnya, (3) melakukan pelatihan pengolahan ubi jalar, (4) evaluasi dan pendampingan dalam diversifikasi produk, (5) bekerjasama dengan pemerintahan desa dalam memasarkan produk melalui program "Menyukai produk dari desa". Langkah pelaksanaan kegiatan dapat dilihat pada Tabel 1.

Tabel 1. Kegiatan Pengelolaan Hasil Pertanian Ubi Jalar

\begin{tabular}{|l|l|l|l|}
\hline No & \multicolumn{1}{|c|}{ Aktifitas } & \multicolumn{1}{c|}{ Metode } & \multicolumn{1}{c|}{ Keterangan } \\
\hline 1. & $\begin{array}{l}\text { Diskusi kondisi awal } \\
\text { calon peserta }\end{array}$ & Paparan interaktif & Alat bantu: kuesioner sederhana \\
\hline 2. & $\begin{array}{l}\text { Pembuatan modul } \\
\text { pengolahan ubi jalar }\end{array}$ & $\begin{array}{l}\text { Diskusi dan } \\
\text { praktikum }\end{array}$ & $\begin{array}{l}\text { Dilakukan oleh anggota pelaksana } \\
\text { berdasarkan hasil langkah 1 }\end{array}$ \\
\hline 3. & $\begin{array}{l}\text { Pelaksanaan } \\
\text { pelatihan }\end{array}$ & Praktikum interaktif & $\begin{array}{l}\text { Anggota pelaksana dan peserta } \\
\text { mempraktekkan modul }\end{array}$ \\
\hline 4. & $\begin{array}{l}\text { Evaluasi dan } \\
\text { pendampingan }\end{array}$ & Diskusi interaktif & $\begin{array}{l}\text { Dilakukan secara aktif selama } \\
\text { periode tertentu }\end{array}$ \\
\hline 5. & Keberlanjutan & $\begin{array}{l}\text { Diskusi interaktif } \\
\text { dan pelaksanaan } \\
\text { bekerjakama dengan pemerintahan } \\
\text { daerah }\end{array}$ \\
\hline
\end{tabular}

Langkah awal dalam proses pengelolaan hasil pertanian ubi jalar adalah melakukan diskusi dengan ibu-ibu PKK. Tujuan dari diskusi ini adalah untuk mengetahui pengetahuan awal ibu-ibu PKK tentang pengolahan ubi jalar dan harapan mereka. Teknik yang digunakan adalah dengan menyebarkan kuesioner sederhana. Data yang diperoleh diolah dengan teknik statistika deskriptif. Hasil olah data menunjukkan pelatihan yang diperlukan calon peserta. Setelah diketahui produk yang akan dilatihkan, yaitu pembuatan tepung, brownis, mie, es krim dan yoghurt dengan bahan dasar ubi jalar, maka langkah selanjutnya adalah menyiapkan modul pelatihan. Modul disusun dengan melibatkan pakar pengolahan makanan berbasis ubi jalar. Modul yang telah disusun digunakan dalam ujicoba pembuatan produk. Uji coba dilakukan oleh tim beserta mahasiswa.

Langkah berikutnya adalah pelaksanaan pelatihan interaktif yang diberikan ke ibuibu PKK desa Selotapak. Pengikut pelatihan ini hanya terbatas pada 30 orang yang merupakan gabungan dari Ibu PKK dan karangtaruna. Pemilihan peserta dilakukan oleh ibu kepala desa dibantu oleh tim penggerak PKK desa Selotapak, dan tidak dilakukan 
secara acak. Peserta yang dipilih adalah masyarakat yang mempunyai minat dalam pengembangan kuliner berbasis ubi jalar dan merupakan perwakilan dari dua dusun serta perwakilan dari tiap RT. Warga yang terpilih diwajibkan untuk berbagi ilmu ke warga lainnya melalui kegiatan rutin PKK.

Pelaksanaan pelatihan interaktif dilakukan dalam 2 kali pertemuan, pertemuan pertama adalah pelatihan pengolahan ubi jalar menjadi tepung, brownis, dan mie, serta pelatihan kedua adalah pembuatan es krim dan yoghurt. Pada setiap pelatihan, setiap orang berkesempatan untuk praktek membuat 5 jenis produk tersebut. Bahan utama ubi jalar diperlukan dalam kondisi mentah dan matang(sudah dikukus). Ubi jalar mentah diperlukan untuk membuat tepung ubi jalar. Tepung ubi jalar dapat digunakan untuk membuat brownis dan mie. Sedangkan ubi jalar kukus digunakan untuk membuat brownis, mie, es krim, dan yoghurt. Jadi pembuatan brownis dan mie dilakukan dengan menggunakan bahan tepung ubi jalar dan ubi jalar kukus.

Alat yang diperlukan pada pembuatan tepung ubi jalar adalah mesin pengering ubi (bisa diganti dengan dikeringkan di bawah sinar matahari) dan mesin penepung, seperti terlihat pada Gambar 1. Sedangkan bahan yang diperlukan hanya ubi jalar mentah saja. Proses pembuatan dimulai dengan membersihkan ubi jalar kemudian mengiris tipis ubi dan dilanjutkan dengan mengeringkannya. Hasil pengeringan didiamkan sebentar untuk selanjutnya ditepungkan.

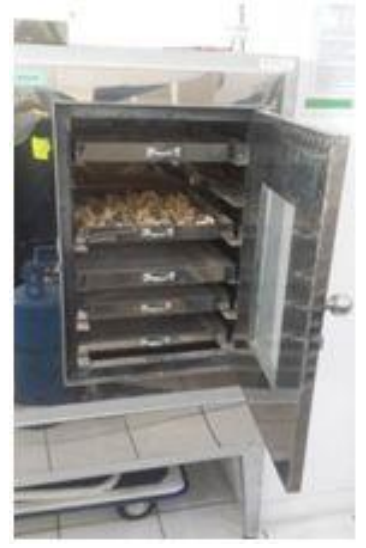

(a) mesin pengering

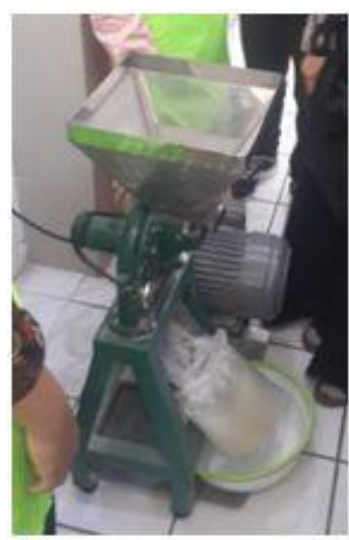

(b) mesin penepung

Gambar 1. Alat Pembuatan Tepung Ubi Jalar

Pada pembuatan brownis ubi jalar diperlukan alat pencampur bahan (mixer), loyang, dan dandang pengukus. Bahan yang diperlukan adalah ubi jalar(tepung atau ubi kukus), tepung terigu, gula, telur, baking powder, SP, dan susu bubuk. Pembuatan 1 resep brownis dengan menggunakan tepung ubi jalar memerlukan campuran 40 gr tepung ubi jalar dengan 80 gram tepung terigu. Sedangkan apabila digunakan ubi kukus maka untuk 1 resep diperlukan 80 gram ubi kukus dicampur dengan 90 gram tepung terigu. Apabila menggunakan ubi kukus, maka sebelum dicampur dengan bahan yang lain, ubi harus dilembutkan terlebih dahulu. Setelah semua bahan tercampur dengan sempurna, baru ubi kukus dimasukkan ke dalam adonan. Jika ubi sudah bercampur dengan bahan yang lain, maka adonan dimasukkan ke dalam loyang dan siap dikukus didandang. Setelah dikukus selama 30-40 menit, brownis siap dihidangkan.

Sedangkan untuk pembuatan mie ubi jalar diperlukan mesin penggiling mie (Gambar 2), timbangan kue, baskom ukuran sedang dan rolling pin. Bahan yang diperlukan dalam pembuatan mie antara lain ubi jalar(tepung atau ubi kukus), tepung terigu, baking powder, garam, telur, minyak dan air. Apabila menggunakan ubi kukus, 
maka untuk 1 resep diperlukan 50 gram ubi kukus dan 100 gram tepung terigu. Apabila menggunakan tepung ubi jalar diperlukan 15 gram tepung ubi jalar dan 100 gram tepung terigu. Cara membuatnya semua bahan mie dicampur dan diuleni sampai kalis. Dengan menggunkan rolling pin adonan digiling dengan ditaburi tepung tipis-tipis. Jika ketebalan sudah sesuai yang diinginkan maka mie mulai ditipiskan di mesin penggiling. Jika sudah diperoleh ketebalan yang diinginkan, maka mie dibentuk di mesin penggiling. Kemudian mie direbus di air mendidih yang telah diberi minyak selama 1-2 menit. Angkat dan tiriskan, dan mie siap untuk diolah. Semua bahan yang diperlukan dapat dengan mudah diperoleh ditoko-toko disekitar tempat tinggal.

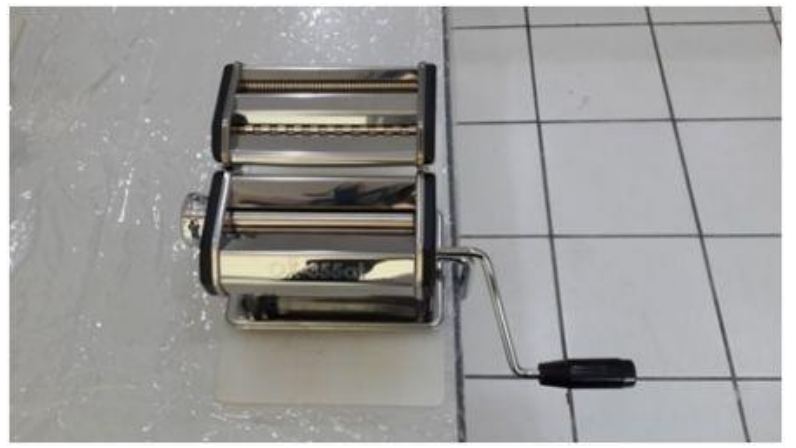

Gambar 2. Alat Pembuat Mie

Pembuatan es krim ubi jalar menggunakan teknologi pembekuan cepat (fast freezing technology). Pada pelatihan ini digunakan mesin es krim goreng. Prinsip kerja mesin adalah melakukan pembekuan bahan secara cepat dengan menggunakan Freon. Pembekuaan terjadi hanya dalam waktu beberapa menit saja. Cepatnya proses pembekuan juga dipengaruhi oleh adonan es krim. Sistem emulsi yang baik akan mempengaruhi karakteristik es krim yang dihasilkan. Pada pelatihan ini diperlukan mesin es krim goreng, panci, pengaduk, kompor, dan alat pengaduk serta penggulung es. Sedangkan bahan yang diperlukan adalah heavy cream, susu cair, gula, tepung maizena, dan ubi jalar. Cara membuatnya, pertama larutkan tepung maizena dengan sedikit susu cair. Campurkan heavy cream, susu cair, dan gula sampai larut sempurna dalam wadah berbeda dengan larutan tepung maizena. Panaskan campuran heavy cream pada api yang kecil. Kemudian tambahkan larutan tepung maizena, dan aduk pelanpelan. Apabila adonan sudah mendidih maka angkat adonan dan biarkan adonan sampai dingin. Jus ubi jalar atau rasa lainnya dapat dicampurkan pada adonan. Setelah adonan dingin, tuangkan adonan di atas pan mesin es krim goreng dengan ketebalan sekitar 2 mm (lihat Gambar 3). Ketika adonan mulai membeku, gulung es krim dengan alat penggulung. Angkat es krim roll dan letakkan dalam gelas/wadah. Es krim roll siap dinikmati dan bisa ditambahkan topping sesuai selera. 


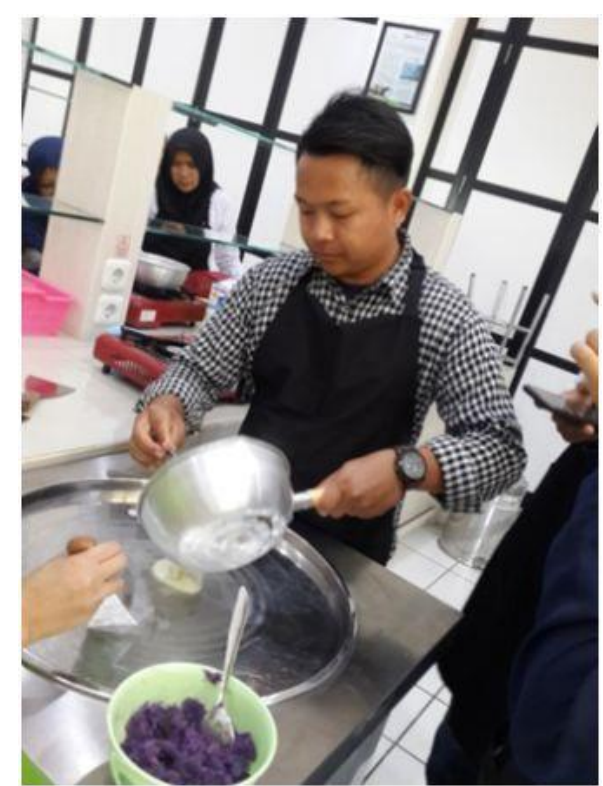

Gambar 3. Proses Pembuat Es Krim Roll

Materi lain yang diberikan pada pelatihan adalah pembuatan yoghurt. Yoghurt merupakan salah satu bentuk olahan susu yang dibuat melalui proses fermentasi dengan penambahan Bakteri Asam Laktat (BAL). Pada pelatihan yang diberikan, bahan yang digunakan adalah susu cair, gula pasir, biokul, dan ubi jalar. Sedangkan alat-alat yang diperlukan adalah panci, blender, spatula, sendok, dan kompor. Cara membuatnya cukup mudah, pertama lembutkan ubi dengan cara di-jus dengan menggunakan blender. Kemudian jus ubi dan gula dipanaskan dengan menggunakan api kecil. Apabila susu belum steril, maka panaskan susu terlebih dahulu. Selanjutnya dinginkan jus ubi dan atau susu, lalu campurkan dan tambahkan starter yoghurt sebanyak 10\%. Pindahkan ke botol-botol kecil dan diamkan (fermentasi) selama 24 jam pada suhu $37^{\circ} \mathrm{C}$. Yoghurt siap dinikmati. Yoghurt bermanfaat untuk menjaga keseimbangan mikroba di sistem pencernaan, menurunkan kadar kolesterol, dan meningkatkan kekebalan tubuh.

\section{HASIL KARYA UTAMA DAN PEMBAHASAN}

Pelatihan pengolahan ubi jalar dilakukan di laboratorium bionutrisi Universitas Surabaya. Penentuan materi pelatihan diperoleh dari hasil kesepakatan dengan warga. Materi pelatihan yang diharapkan diperoleh dengan cara menanyai langsung ibu-ibu PKK saat acara pertemuan rutin. Setiap ibu yang hadir diberi selembar kertas yang berisi beberapa pertanyaan dalam bentuk pilihan (tertutup) dan mengisi jawaban (pertanyaan terbuka) tentang kondisi awal calon peserta dan jenis pelatihan yang diharapkan. Setiap ibu PKK diminta untuk memilih jenis pelatihan yang diinginkan. Berdasarkan hasil angket diperoleh 7 jenis pelatihan pengolahan ubi jalar terbanyak yang diinginkan adalah pelatihan pembuatan tepung, mie, es krim, brownis, stik keju, snack, dan yoghurt. Hasil selengkapnya dapat dilihat pada Gambar 4. Dari ketujuh materi yang dipilih, materi yang diberikan adalah pembuatan tepung ubi jalar, mie ubi jalar, brownis ubi jalar, es krim roll ubi jalar, dan yoghurt ubi jalar. 


\section{Materi Pelatihan yang Diinginkan}

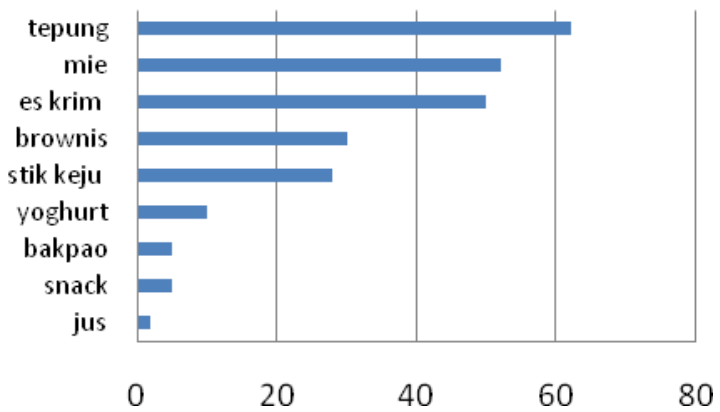

Gambar 4. Materi Pelatihan yang Diinginkan Peserta

Pada saat pelatihan ada 1 orang yang berhalangan hadir, sehingga jumlah peserta adalah 29 orang, yang terdiri dari 26 orang perempuan dan 3 orang laki-laki. Hampir semua peserta pernah membuat olahan ubi jalar, hanya 5 orang saja yang sama sekali belum pernah melakukannya. Dari 24 orang yang pernah melakukan pengolahan ubi jalar, semuanya pernah membuat keripik ubi jalar, 9 orang pernah membuat carang mas, dan 2 orang pernah mencoba untuk membuat kue dari ubi jalar. Karena hampir semua pernah membuat olahan ubi jalar, maka semua bahan dan alat yang dipergunakan sudah tidak asing lagi bagi peserta.

Pelaksanaan pelatihan dilakukan dalam 2 kali pertemuan. Pertemuan pertama diberikan pelatihan pembuatan tepung ubi jalar, mie ubi jalar dan brownis ubi jalar. Kali ini semua peserta dibagi menjadi 3 kelompok kecil dan setiap kelompok secara bergantian akan praktek dalam pembuatan tepung ubi jalar, brownis ubi jalar, mie ubi jalar. Pada pertemuan kedua diberikan pelatihan pembuatan es krim roll ubi jalar, dan yoghurt ubi jalar. Pada pertemua kedua, semua peserta dibagi menjadi 2 kelompok. Setiap peserta akan prokterk secara langsung pembuatan dua produk tersebut. Produk hasil pelatihan dapat dilihat pada Gambar 5. Pada setiap pelatihan akan ada 1 orang instrukstur dan 2 orang asisten yang akan memandu dan membantu peserta saat pelatihan berlangsung. 


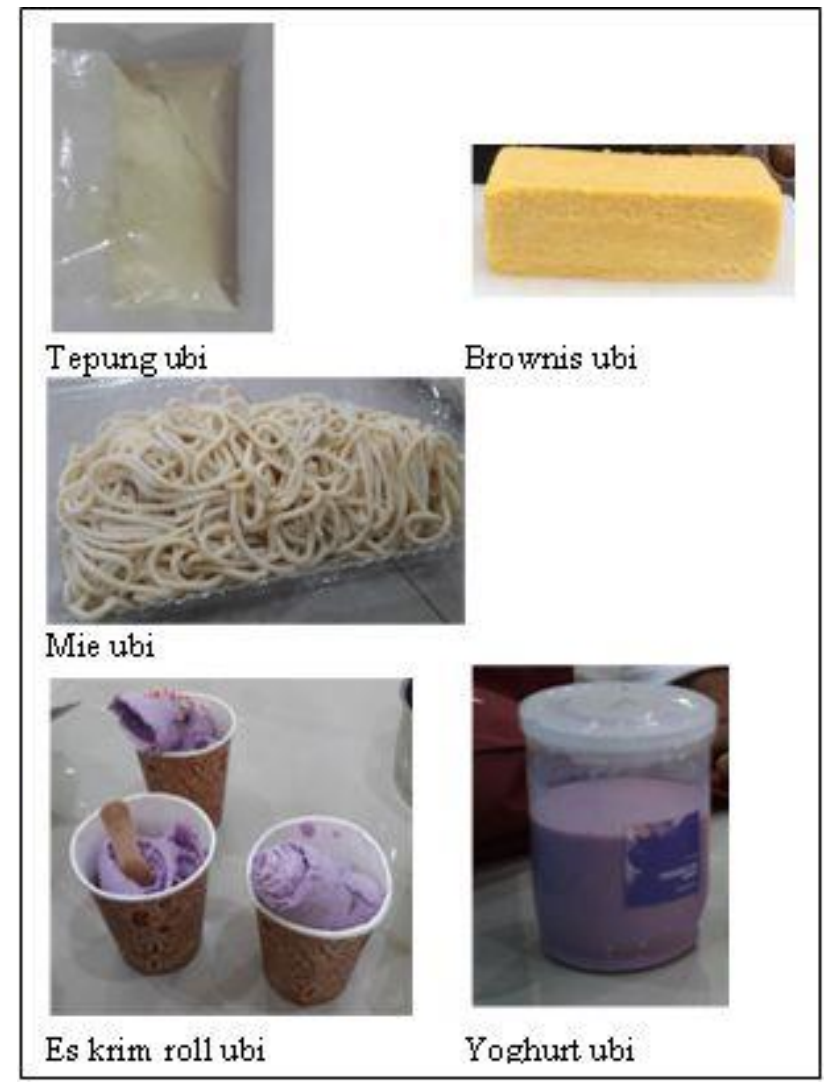

Gambar 5. Produk Hasil Pelatihan

Setelah mengikuti semua pelatihan tersebut, setiap peserta diminta untuk memberikan penilaian terkait dengan pelaksanaan kegiatan. Hasil penilaian untuk materi pelatihan adalah hampir semua peserta(83\%) menyatakan bahwa materi yang disajikan baik dan baik sekali. Ada 2 peserta yang memberi tambahan keterangan bahwa mereka sama sekali belum pernah membuat produk olahan ubi jalar, namun dengan mengikuti pelatihan ini mereka bisa dan menjadi mengerti akan materi serta dapat menghasilkan produk olahan ubi jalar, jadi menurut mereka materi telah disajikan dengan sangat baik. Terdapat $17 \%$ yang menyatakan isi materi cukup baik. Menurut $17 \%$ peserta ini materi yang diberikan sudah pernah mereka dapat, hanya materi tepung ubi jalar, es krim roll, dan yoghurt saja yang baru. Selain itu ada juga yang berpendapat bahwa materinya agak susah sehingga yang bersangkutan sempat ketinggalan penjelasan materi. Hasil selengkapnya dapat dilihat pada Gambar 6.

\section{Penilaian Isi materi}

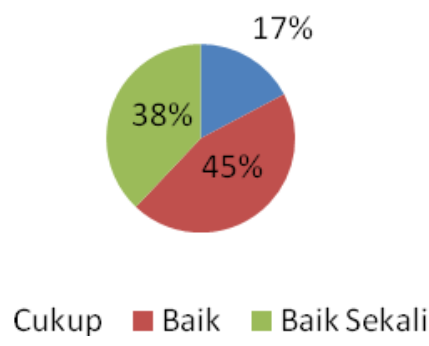

Gambar 6. Penilaian Terhadap Isi Materi 
Ketika diminta pendapatnya tentang kemungkinan menerapkan materi pelatihan di tempat masing-masing secara mandiri, $86 \%$ menjawab bisa atau sangat bisa diterapkan, mengingat kemudahan materi dan kemudahan mendapatkan bahan serta alat. Satu peserta tidak mengisi pertanyaan ini, dan $10 \%$ menyatakan cukup bisa diterapkan. Alasan cukup bisa diterapkan karena di desa Selotapak tidak ada mesin penepung dan mesin pengering. Beberapa peserta tidak mengetahui bahwa pemerintahan desa mempunyai mesin pengering yang diletakkan dibalai desa. Seandainya mesin pengering tidak ada maka proses pengeringan ubi jalar dapat dilakukan secara manual, yaitu pengeringan di bawah sinar matahari langsung. Untuk skala kecil, proses penepungan juga bisa dilakukan dengan menggunakan blender biji-bijian. Kemudahan pengadaan alat membuat ibu-ibu dapat mempraktekkan pembuatan tepung secara mandiri. Hasil penilaian peserta secara lengkap dapat dilihat pada Gambar 7.

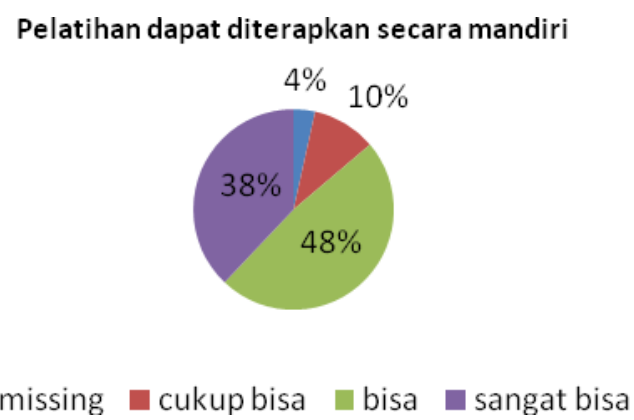

Gambar 7. Penilaian Terhadap Penerapan Materi Secara Mandiri

Secara umum, peserta berpendapat bahwa pelatihan yang diberikan memberi manfaat bagi mereka, lihat Gambar 8. Ada 1 peserta (3\%) yang tidak mengisi pernyataan ini dan ada $7 \%$ peserta yang merasa cukup mendapatkan manfaatnya karena hanya 3 materi yang dianggap baru, sedangkan 2 materi lainnya pernah mereka dapatkan pada pelatihan yang pernah diikuti. Perihal manfaat apa saja yang diperoleh, ada yang menyatakan bahwa pelatihan ini memberi mereka pengetahuan baru dalam memanfaatkan ubi jalar. Sebelumnya, sepengetahuan mereka ubi jalar hanya bisa diolah menjadi keripik, carang mas atau kue dan tidak sampai menjadi tepung atau mie, atau bahkan es krim yang rasanya enak. Ada juga yang berpendapat bahwa dengan pelatihan ini pikiran mereka jadi terbuka bahwa peralatan yang dibutuhkan dalam mengolah ubi jalar relatif sederhana, murah dan mudah didapat. Sebelumnya, dalam bayangan mereka untuk mengolah ubi jalar menjadi tepung merupakan hal yang tidak mengkin dilakukan secara individu karena alat yang diperlukan dirasa sangat mahal dan susah dicari.

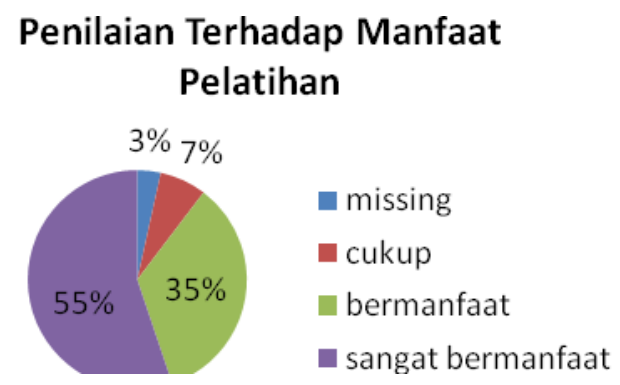

Gambar 8. Penilaian Terhadap Manfaat Pelatihan 
Sebelumnya beberapa peserta juga pernah mengikuti pelatihan pembuatan olahan ubi jalar, namun tidak semua orang bisa praktek secara langsung. Hal ini disebabkan jumlah peralatan yang terbatas, sehingga 1 kelompok yang terdiri dari 5-6 orang mencoba bersama. Pada pelatihan yang diberikan oleh tim pengabdian ini, saat praktek tiap orang memang masuk dalam kelompok tapi jumlah anggota perkelompok hanya 2 orang saja, sehingga setiap orang harus ikut aktif membuat produk yang dipraktekkan.

Meningkatnya pengetahuan peserta dalam mengolah ubi jalar setelah mengikuti pelatihan menjadi salah satu tolak ukur keberhasilan pelatihan. Pengukuran peningkatan pengetahuan peserta dilakukan dengan cara membandingkan pengetahuan yang dimiliki sebelum dan sesudah pelatihan melalui kuesioner. Semua peserta berpendapat bahwa pelatihan kali ini membuat mereka jadi mengerti bagaimana cara mengolah ubi jalar karena mereka secara langsung praktek membuat produk, tidak hanya melihat saja. Beberapa orang, dari karangtaruna dan ibu-ibu muda, mengaku bahwa mereka baru pertama kalinya membuat mie, tepung, es krim dan yoghurt pada pelatihan ini. Sebelumnya mereka menganggap kalau mie, tepung, es krim dan yoghurt hanya bisa dibuat oleh industri kecil. Perubahan yang dirasakan peserta terangkum dalam Tabel 2.

Tabel 2. Perubahan Pengetahuan Pengolahan Ubi Jalar

\begin{tabular}{|c|c|c|}
\hline & Sebelum Pelatihan & Sesudah Pelatihan \\
\hline $\begin{array}{l}\text { Peningkatan } \\
\text { nilai ekonomi } \\
\text { ubi jalar }\end{array}$ & $\begin{array}{l}\text { Ubi jalar dijual mentah } \\
\text { ke tengkulak }\end{array}$ & $\begin{array}{l}\text { Sebagian Ubi jalar diolah untuk menjadi } \\
\text { produk unggulan desa }\end{array}$ \\
\hline $\begin{array}{l}\text { Produk } \\
\text { olahan ubi } \\
\text { jalar }\end{array}$ & $\begin{array}{l}\text { - Keripik ubi jalar } \\
\text { - } \quad \text { Carang mas ubi } \\
\text { jalar }\end{array}$ & $\begin{array}{ll}\text { - } & \text { Keripik ubi jalar } \\
\text { - } & \text { Carang mas ubi jalar } \\
\text { - } & \text { Tepung ubi jalar } \\
\text { - } & \text { Brownis ubi jalar } \\
\text { - } & \text { Mie ubi jalar } \\
\text { - } & \text { Es krim ubi jalar } \\
\text { - } & \text { Yoghurt ubi jalar }\end{array}$ \\
\hline $\begin{array}{l}\text { Masa simpan } \\
\text { ubi jalar }\end{array}$ & 4-5 hari & $\begin{array}{l}\text { Dengan dibuat menjadi tepung ubi jalar, } \\
\text { masa simpan bisa sampai } 1 \text { bulan }\end{array}$ \\
\hline
\end{tabular}

Hasil pelatihan interaktif yang telah dilakukan oleh tim pelaksana, memperlihatkan bahwa produk olahan ubi jalar yang dihasilkan sudah lebih bervariasi dan ada alternative lain dalam menyimpan ubi jalar sehingga tidak cepat rusak. Namun masih perlu dipikirkan proses pengemasan dan sertifikasi produk olahan ini agar layak untuk dijual bebas. Penyempurnaan proses dilakukan pada langkah selanjutnya, yaitu evaluasi dan pendampingan dalam keberlanjutan produk.

Berdasarkan kritik dan saran untuk kegiatan serupa di kemudian hari, 90\% peserta memberikan komentar bahwa pelatihan yang diberikan menjadi pengetahuan baru bagi mereka dalam pengolahan ubi jalar. Harapannya tim pelaksana akan mengadakan pelatihan serupa dengan topik yang berbeda sehingga referensi olahan ubi jalar semakin banyak. Beberapa produk olahan yang ingin dilatihkan adalah pembuatan makanan ringan berbasis ubi jalar, cookies, dan inovasi keripik ubi jalar. Dengan pengetahuan ini, disaat masa panen ubi jalar, peserta mempunyai pilihan lain untuk menjual ubi jalarnya, tidak hanya dalam kondisi mentah. Sehingga hal ini dapat menambah pendapatan 
keluarga. Selain itu, ada saran untuk ikut membantu dalam memasarkan produk, pelatihan pemasaran secara online, pelatihan pembuatan kemasan, dan meminta bantuan alat penepung dan kemasan.

Untuk pemasaran produk, langkah awal yang dapat dilakukan adalah bekerjasama dengan pemerintah desa dalam program "menyukai produk dari desa" untuk warga Selotapak. Selain itu, pada beberapa kegiatan desa, baik kegiatan internal atau mengundang tamu dari luar desa, pemerintah juga sudah menyarankan untuk menyajikan produk olahan ubi jalar sebagai bagian snack kegiatan. Saat ini memang belum ada aturan atau edaran yang mewajibkan hal tersebut, jadi penggunaan snack dari ubi jalar masih berupa himbauan. Pembagian pembuatan kue dikoordinasi oleh PKK, sehingga secara bergantian warga yang berkeinginan untuk menekuni pembuaatan produk olahan ini dapat berpartisipasi pada kegiatan. Produk olahan ubi jalar ini direncanakan akan menjadi produk unggulan desa Selotapak.

\section{KESIMPULAN}

Berdasarkan hasil diskusi dan pelatihan dapat disimpulkan bahwa permasalahan harga ubi jalar yang rendah saat panen raya dapat diminimalkan dengan mengolah ubi jalar tersebut menjadi produk tertentu. Hasil olahan ubi jalar menjadi tepung membuat masa simpannya lebih panjang (semula hanya 4-5 hari menjadi 1 bulan) dan nilai ekonominya lebih tinggi. Lebih dari $80 \%$ peserta pelatihan merasakan manfaat pelatihan dan menyatakan bahwa materi yang diberikan dapat diterapkan secara mandiri saat peserta kembali ke desa Selotapak. Selain itu terjadi peningkatan pengetahuan peserta tentang pengolahan ubi jalar, jika sebelum pelatihan rata-rata hanya bisa mengolah ubi jalar menjadi keripik dan carang mas, maka setelah pelatihan terdapat 5 produk baru olahan ubi jalar.

Pengemasan, sertifikasi serta pemasaran produk menjadi bagian selanjutnya yang perlu untuk dipikirkan. Peranan pemerintah desa sangat besar dalam rangka pemasaran di internal desa. Slogan "menyukai produk desa sendiri" dapat diviralkan. Pemerintah mewajibkan penggunaan olahan ubi jalar untuk konsumsi kegiatan desa. Selain itu pemerintah desa juga bisa menfasilitasi kerjasama dengan lembaga di luar desa dalam memperkenalkan produk unggulannya.

Untuk mendukung pemasaran produk, maka diperlukan media promosi. Media tersebut meliputi media online atau offline. Pemasaran produk dapat dilakukan melalui instagram, facebook, whatsapp, dan lainnya. Sedangkan pemasaran offline bisa dilakukan dengan cara membuat brosur, pamflet dan lainnya untuk dititipkan di tempat wisata sekitar desa Selotapak. Pemasaran dari mulut ke mulut menjadi bagian yang tidak terpisahkan dalam pemasaran produk.

Agar pengetahuan peserta tidak hilang setelah pelatihan, maka perlu disusun kegiatan yang berkesinambungan untuk melakukan inovasi produk berbasis ubi jalar. Dengan kegiatan yang berkelanjutan, warga lain yang belum bisa mengikuti secara langsung pelatihan dapat belajar pada kesempatan tersebut.

\section{UcapanTerima Kasih}

Ucapan terima kasih kami sampaikan terutama kepada Direktorat Riset dan Pengabdian Masyarakat, Direktotar Jenderal Penguatan Riset dan Pengembangan, Kementerian Riset, Teknologi, dan Pendidikan Tinggi sesuai dengan perjanjian pendanaan pelaksanaan program Pengabdian Kepada Masyarakat Nomor: 004/SP2H/PPM/L7/2019, tanggal 26 Maret 2019. 


\section{REFERENSI}

Ginting E., Utomo J.S., Yulifianti R., Jusuf M.. 2011. Potensi Ubijalar Ungu sebagai Pangan Fungsional. Iptek Tanaman Pangan. Vol. 6 No. 1

Moyer, J.M. 1982. Post Harvest Diseases Management for Sweet Potatoes. Asian Vegetable Research and Development Center, Shanhua, Taiwan

Rahayu P., Fathonah S., Fajri M. 2012. Daya Terima dan Kandungan Gizi Makanan Tambahan Berbahan Dasar Ubi Jalar Ungu. Food Science and Culinary Education Journal. Universitas Negeri Semarang. ISSN 2252-6587

Soetanto, E. 1998. Membuat Keripik Ubi jalar Rasa Gadung. Penerbit Kanisius, Yogyakarta

Syarfaini, Satrianegara, M.F., Alam S, Amriani. 2017. Analisis Kandungan Zat Gizi Biskuit Ubi Jalar Ungu(Ipomoea batatas L. Poiret) Sebagai Alternatif Perbaikan Gizi di Masyarakat. Public Health Science Journal Volume 9, Nomor 2, JuliDesember 2017

Trisnawati N.A., Jatiningsih A. 2017. Strategi Pemberdayaan Kesejahteraan Keluarga (PKK) dalam Pemberdayaan Perempuan di Kelurahan Sukorame Kecamatan Gresik Kabupaten Gresik. Kajian Moral dan Kewarganegaraan, Volume 05 Nomor 03 Tahun 2017, 486-500

Widjanarko, S.B. 2008. Efek Pengolahan Terhadap Komposisi Kimia dan Fisik Ubi Jalar Ungu dan kuning. http://simonbwidjanarko.wordpress.com/2008/06/19/efekpengolahanterhadap-komposisi-kimia-fisik-ubi-jalar-ungu-dan-kuning/.[4 Februari 2014]. 